\title{
Supply Capability Creation Process: Key Milestone Criteria and Activities
}

\author{
Jordan Verrollot (iD, Arto Tolonen (D), Janne Harkonen (D), Harri Haapasalo iD \\ University of Oulu (Finland) \\ jordan.verrollot@,oulu.fi, arto.tolonen@,oulu.fi,janne.barkonen@,oulu.fi, barri.baapasalo@,oulu.fi
}

Received: June 2017

Accepted: August 2017

\section{Abstract:}

Purpose: The article focuses on supply capability creation (SCC) within the new product development (NPD). The purpose is to establish an SCC process describing the main SCC activities and milestone criteria in preparing the supply process for new products

Design/methodology/approach: The article analyses the earlier research, carries out current state analysis of six case companies regarding the SCC areas and proposes an SCC process.

Findings: The developed SCC process aims at preparing the operational supply capability for a developed new product based on the preferred, qualified and contracted suppliers and materials along the NPD process, and ultimately at the product ramp-up.

Originality/value: This paper introduces an SCC process that has not been presented earlier in the literature, highlighting the important role of the SCC for successful product ramp-ups.

Keywords: new product development, NPD, supply-chain management, supply-chain capability creation, supply management, supply capability creation, procurement 


\section{Introduction}

Considering increased global competitive pressures, growing product variety and decreasing product life cycles, companies are focusing more than ever on the new product development (NPD) success (Koufteros, Vonderembse \& Doll, 2002; Petersen, Handfield \& Ragatz, 2005). The rapid, smooth and economic development and launch of successful new products are increasingly critical to allow business success, market leadership, high competitiveness and sustainable growth (Bernard \& Fischer, 2002; Minderhoud \& Fraser, 2005; Dereli, Baykasoglu \& Buyukozkan, 2008; Bhuiyan, 2011; Barczak \& Kahn, 2012). One perspective to improve NPD has been to integrate the supply-chain with the product development. Carrillo and Franza (2006) argue that the NPD process must be involved in the ramp-up of the supply-chain processes and other activities that support the commercialization of newly developed products. Instead of preparing the supply-chain capability after the NPD project, the supply-chain capability creation related issues should be handled by supply-chain (SC) process representatives from the beginning of product development (Van Hoek \& Chapman, 2007).

Although various scientific and practice-oriented studies have been published in the fields of NPD process and SC process, they are relatively not considered together. This disinterest prevents to exploit the benefits of an integrated view on product development and SC processes (Caniato \& Größler, 2015). The few contributions focusing on the coordination of NPD and SC (e.g. Hillebrand \& Biemans, 2004; Carrillo \& Franza, 2006; Van Hoek \& Chapman, 2007, Hilletofth, Ericsson \& Lumsden, 2010; Pero, Abdelkafi, Sianesi \& Blecker, 2010; Marsillac \& Roh, 2014) show the need and the potential for further investigation of this field of study. The lack of wider research addressing these issues is surprising since short time-to-market, total cost and product performance are affected by various SC activities. For instance, the development of a new product may become challenging, when the supply of specific materials or components is not secured efficiently. Thus, integrating the two functional areas is certainly beneficial (Caniato \& Größler, 2015). Being part of the NPD-SC coordination, this study aims at exploring the supply capability creation (SCC) process as a part of supply-chain capability creation (SCCC). The SCCC capability can be seen as the performance of the operational supply-chain process to execute its activities according to agreed performance targets and metrics (Lummus \& Vokurka, 1999; Swafford, Ghosh \& Murthy, 2006). The previous research scarcely addresses how the supply-chain processes readiness (i.e. capability) could be established systematically along the NPD process phases and milestones for the new product.

The importance of supply management (SM) and its involvement in the product development process have grown due to the trend of companies concentrating on their core competencies, eventually leading to increasing levels of outsourcing and purchasing (Choi \& Krause, 2006; McIvor, Humphreys \& Cadden, 2006; Shamsuzzoha, Takala \& Helo, 2010). Having subcontracted large parts of their 
production, companies rely heavily on their suppliers (Wynstra, Weele, \& Axelsson, 1999) which are seen to exert a major influence on a firm's success or failure (Ellram \& Carr, 1994; Carr, Kaynak, Hartley \& Ross, 2008). The role of SM is to identify the company's supply requirements, develop supply strategies as well as to select and manage proficient suppliers to realise combined performance advantages (Goffin, Szwejczewski \& New, 1997; Jack \& Powers, 2015). Compared to the extensive literature on supplier involvement and its potential benefit on the NPD, relatively limited study has been realised on the SM role (Luzzini, Amann, Caniato, Essig \& Ronchi, 2015). However, SM involvement in NPD is seen crucial for the success of the product introduction and innovation performance (McGinnis \& Vallopra, 1999; Nijssen, Biemans \& De Kort, 2002; Luzzini et al., 2015).

Previous research highlights the benefits of involving the SM stakeholders during the NPD process but does not explain how the supply readiness can be built alongside the NPD process. This study aims at analysing the relevant earlier research and case companies' current practices of supply capability creation, to examine the linkage between NPD process and supply process. The major part of the study involves the current state analysis of six companies' practices focusing on the NPD process and more particularly on the concept of SCC process to analyses the systematic supply capability readiness for new products.

The above discussion is condensed into the following research questions (RQs):

RQ1: What are the areas of SCC found in literature?

RQ2: What are the current practices of SCC in the studied companies?

RQ3: How could SCC be systematically handled as a process?

Section two focuses on identifying the literature on NPD process, SC process, SCCC and SCC (RQ1). The research process and method are discussed in section three. Section four presents the current state analysis and challenges of six companies concerning SCC (RQ2). The proposal for systematic SCC process is introduced in section five (RQ3). Finally, section six presents the discussion and conclusions. 


\section{Literature Review}

The investments in new technologies, the cost of product development, the shortening product life cycles and the growing number of new products make the success of ramp-ups an increasingly important managerial topic (Almgren, 1999; Cooper, 2001; Terwiesch, Bohn \& Chea, 2001; Pufall, Fransoo \& de Kok, 2007). The increasing product variety influences the SC cost and efficiency (Um, Lyons, Lam, Cheng \& Dominquez-Pery, 2017). Complex product structures, projects, production and supply-chain networks set particular challenges at the ramp-up phase (Von Cube \& Schmitt, 2014). Furthermore, the speed of the ramp-up strongly affects the time-to-volume of a product and subsequently the financial success of the new product and the company (Haller, Peikert \& Thoma, 2003). All those issues can be managed by integrating NPD and SC processes by SCCC activities (Lakemond, Echtelt \& Wynstra, 2001; Ball, Roberts, Natalicchio \& Scorzafave, 2011; Elstner \& Krause, 2014; Surbier, Alpan \& Blanco, 2014; Caniato \& Größler, 2015).

\subsection{New Product Development Process}

The New Product Development (NPD) process aims at moving new products from idea generation into market introduction, including product design, market study and marketing analyses (Cooper, 2001; Otto \& Wood, 2001; Ulrich \& Eppinger, 2008). NPD process consists of sequential steps or set of activities beginning with the perception of a market opportunity and ending in the sales, production and delivery of a product (Ulrich \& Eppinger, 2008). Since the 90s, some NPD frameworks (e.g. Anthony \& McKay, 1992; Cooper, 2001; Ulrich \& Eppinger, 2008) have been developed to meet the various needs of organisations. These frameworks include important features which, when accomplished in a balanced and efficient manner, can significantly enhance the NPD performance. Those features consist of 1) the use of a structured development process, described milestones' criteria, primary tasks, schedule, and resource assignments; 2) a review board who provide the oversight of the projects by resolving cross-project issues, setting projects' priorities, and make go/kill decisions; 3) the use of realization and crossfunctional teams; 4) phase/gate reviews at major development milestones, when funding, resources and project schedules are approved, rejected, or postponed by the review board (Gehani, 1992; Shepherd \& Ahmed, 2000; Ahmed \& Rafiq, 2002). The typical NPD phases (P) can be defined as P0 feasibility study, P1 project planning, P2 concept development, P3 development and integration, P4 piloting and P5 rampup (Cooper, 2001; Ulrich \& Eppinger, 2008; Pahl \& Beitz, 2013). The NPD starts with the project order that is based on the product and long-term firm strategies. From the project order, the generation, collection and evaluation of business opportunities and ideas occur (P0). At the next step (P1), the first definition and requirement of the product, the objectives as well as the project planning are established. 
During the concept development (P2), the product definition and architecture from the perspective of its functions and components are developed. The detailed and concrete design and development of the product take place during the product development and integration (P3). The supply-chain is also fully involved in this potentially long stage. During the next phase (P4), the tests and trials occur to validate the product and the related production, supply management, marketing, etc. The ramp-up phase (P5) with the beginning of full-scale production and selling complete the NPD project (Cooper, 2001; Ulrich \& Eppinger, 2008; Pahl \& Beitz, 2013; Behncke, Eichinger \& Lindemann, 2014).

\subsection{Supply-chain Capability Creation Process}

The SCCC can be seen in the literature as a sub-process of the NPD process, one that handles the preparation of the supply-chain readiness to deliver the product at product ramp-up phase and beyond. The SCCC process consists of subprocesses, including supply, production and logistics capability creation (Tan, 2001; Kim, 2006). The aim of the SCCC is to prepare smooth, efficient, economical and rapid product ramp-ups based on the mature supply-chain process (Carrillo \& Franza, 2006; Hüntelmann, Reinsch \& Märtens, 2007).

Lately, the attention on the issues related to the linkage and interrelationship between NPD and supply-chain (SC) has increased in research and practice (Pero et al., 2010; Caniato \& Größler, 2015). SC and NPD processes are highly connected because the supply-chains supply, produce and distribute the products defined during the product development activities (Pero et al., 2010). One success factor of product development projects involves the integration of several business processes in the NPD process (known as integrated or simultaneous product development), such as supply, production and logistics sub-processes (Kärkkäinen, Piippo \& Tuominen, 2001; Cooper, Edgett \& Kleinschmidt, 2004; Barczak, Griffin \& Kahn, 2009; Schmidt, Sarangee \& Montoya, 2009). Involving and informing supply-chain partners before the launch of new products is important to secure the product ramp-up capability and increase the success of new product development (Ragatz, Handfield \& Scannell, 1997; Wynstra \& Ten Pierick 2000). The supply-chain stakeholders can provide feedback during the different product development stages so that the product and supply-chain design can be handled in parallel (Chen, Reilly \& Lynn, 2005; Carrillo \& Franza, 2006; Hilletofth et al., 2010). Furthermore, new product technologies may also require the development and implementation of new manufacturing technologies requiring cross-functional collaboration between the NPD and SC organisations (Marsillac \& Roh, 2014). Not involving the suppliers in the production decisions may lead to high costs and low production capacity (Chen, Damanpour \& Reilly, 2010). The alignment of SC and NPD processes enhances the effectiveness and efficiency of product ramp-ups as well as the firm overall performance (Salvador, Forza \& Rungtusanatham, 2002; Van Hoek \& Chapman, 2006; 
Selldin \& Olhager, 2007). The goal of the NPD process is not only to develop new products technically but also to assist the ramp-up of the supply-chain activities as early as possible, which then implies to involve the supply-chain representatives into the NPD process (Van Echtelt, Wynstra, Van Weele \& Duysters, 2008; Hilletofth et al, 2010). Therefore, a well-documented NPD and SCCC processes is necessary already in the early phase of NPD in order to prepare the operational supplychain capabilities, including related investments and decisions in a timely manner, and to avoid rampup delays due to too late capability creation activities (Tracey, Lin, \& Vonderembse, 2005; Carrillo \& Franza, 2006; Khan, Barczak, Nicholas, Ledwith \& Perks, 2012). The main targets of the new product ramp-ups are related to mature supply-chain capability at the targeted cost, capacity, time and quality (Hüntelmann et al., 2007; Pufall et al., 2007; Elstner \& Krause, 2014; Stauder, Buchholz, Klocke \& Mattfeld, 2014; Surbier et al., 2014).

\subsection{Supply Capability Creation Process}

Supply Management (SM) identifies the firm's supply requirements, develops supply strategies, as well as selects and manages a suitable set of innovative suppliers to realise combined performance advantages (Trent, 2007; Spina, Caniato, Luzzini \& Ronchi, 2013; Jack \& Powers, 2015). Specific but non-exhaustive - SM objectives have been defined as 1) developing integrated SM strategies to support organizational goals and strategy, 2) obtaining the best quality purchase at a minimum cost and continually reducing the total cost of purchases, 3) developing satisfactory sources of supply as well as negotiating, maintaining healthy relationships and securing optimal performance with suppliers, and 4) maintaining supply continuity by keeping inventories throughout the supply-chain as low as is consistent with company needs (Burt \& Pinkerton, 1996, Pooler, Pooler \& Farney, 2007; Monczka, Handfield, Giunipero \& Patterson, 2015). To describe the supply process, the literature provides numerous models, which are created from four main phases: information, negotiation, settlement and after-sales phase (Kim \& Shunk, 2004; Behncke et al., 2014). During the information phase, the buyer identifies and anticipates material/service needs, searches for potential new suppliers as well as requests proposals, quotes and bids from preferred or contracted suppliers (Dobler \& Burt, 1996; Kraut, Steinfield, Chan, Butler \& Hoag, 1998; Zsidisin \& Ellram, 2001). Afterwards, acquisition terms such as price, quality, payment conditions or customization are arranged and negotiated during the negotiation phase (Kraut et al., 1998; Gebauer \& Scharl, 1999; Goodchild, Herring \& Milosevic, 2000; Grieger, 2003). Once the contract has been concluded, the settlement phase occurs. The activities such as purchase, shipment, delivery, payment or quality monitoring take place based on the contract terms (Lindmann \& Schmid. 1998; Grieger, 2003; Skjøtt-Larsen, Kotzab \& Grieger, 2003). Eventually, the after-sales phase comprises orders' evaluation, supplier performance measurements as 
well as the consumption, maintenance and disposal of the supplied goods and services (Kraut et al., 1998; Goodchild et al., 2000; Scharl, Gebauer \& Bauer, 2001).

Supply capability creation (SCC) during the NPD phase aims at efficient product ramp-ups and volume phase production through mature supply processes (Almgren, 1999; Pufall, Fransoo, de Jong \& de Kok, 2012). The most typical challenge for production ramp-up related to supply process is the lack of right materials and components from the suppliers due to the competence gaps and immature processes (Almgren, 1999; Pufall et al., 2012). The supply lead-times play a major role in the overall time-to-market, where most time is consumed in selecting suppliers and maintaining supplier relationships (Brewer, Ashenbaum \& Carter, 2013; Brewer \& Arnette, 2017). The early involvement and integration of the key suppliers into the product development process potentially enables lower costs, better product and shortened time-to-market (Petersen et al., 2005). Wynstra et al. (1999) proposed a framework of specific activities within purchasing involvement in product development. Some activities are connected to the SCC - such as formulating policies for purchasing related activities of internal departments, coordinating development activities between suppliers and manufacturers or ordering and chasing prototypes - but it mostly reflects the activities within influencing the product design and involving suppliers in product development. Behncke et al. (2014) proposed a supply management process capable of capturing the early involvement of SM in NPD. The process presents some issues somewhat related to the SCC such as 1) sharing suggestions regarding availability, quality, cost and delivery times of certain components that need to be purchased, 2) SM as a coordinator between the in-house and the supplier's development, or 3) monitoring the performance of vendors. The study, though, does not explain when those activities should be done along the NPD process and focuses on activities outside the SCC scope (e.g. influence on the product design).

Different supply capability creation areas (RQ1) have been found in the literature. The general requirement for SCC includes an integrated and cross-functional NPD in which supply specialists are involved early during the NPD process (1). Effective and efficient SCC implies a structured and described NPD process (2) including milestone criteria (3). Additionally, the SCC process should be outlined in the form of activities implemented during the NPD process (4) to prepare the supply process for the product ramp-up phase and beyond. Milestone criteria for the SCCC process and underlying SCC process should also be established (5). The main activities of SCC consist of selecting, qualifying and contracting suppliers and materials promptly alongside the NPD process (6). 


\section{Research Process and Method}

This research utilises qualitative and inductive research logic. The research process is presented in Figure 1

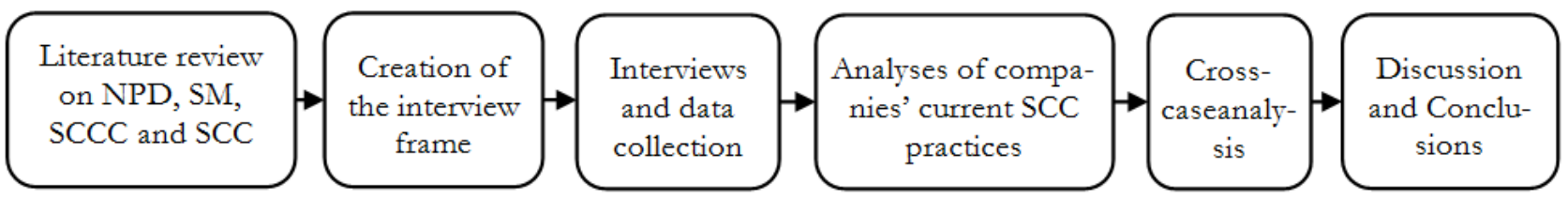

Figure 1. Research process

The literature was reviewed to obtain a necessary understanding of new product development, supply management, supply-chain capability creation and supply capability creation to provide a basis for developing the interview questionnaire. The following empirical analyses were carried out in six companies operating in different business areas (Hardware, Software and Service products), covering various industries (Table 1). The main selection criteria were the companies' activeness in product development projects, and their aims to improve their ways of creating the supply process readiness for developed new products.

Qualitative research data were collected by establishing and implementing a same semi-structured interview frame in all six analysed companies. The questionnaire and the data analysis were divided into new product development process and its subprocesses, supply-chain and its subprocesses, structure and roles of the NPD team, SCCC and the underlying SCC. The basic questions included: the scope and sub-activities of the NPD process; the scope and sub-activities of the supply-chain and supply process, the structure, organisation and roles within the NPD project management teams; the level of proactivity and reactivity of the SCCC and SCC; the structure, roles and responsibilities within SCCC and SCC; the SCC activities during the NPD phases; the targets and metrics of the SCCC and SCC. The interviewees were allowed to explain their company practices as entities and complementary questions were presented when necessary to obtain more details and to focus the discussion. The basic questions, however, remained the same throughout all the interviews. The interviews (Table 1) were conducted with a total of 19 relevant company representatives, selected due to their professional background and expertise (cf. Eisenhardt, 1989). At each company, the interviews were organised as semi-structured group interviews with all the informants present at the same time, allowing multiple respondents to provide relevant input and different viewpoints across functions and hierarchy within the organisation (Barczak, Kahn \& Moss, 2006). Also, the group 
interviews helped to identify potential conflicts, and misalignments in the informants' responses (Yin, 2003).

The eleven semi-structured interview sessions were conducted independently by six different researcher groups. The interview questionnaires were sent beforehand so that the informants had the opportunity to get accustomed with the questions and seek answers before the interviews. All the interview sessions were carried out face-to-face at the companies' premises, except for company B who opted for a conference call. After the interviews, a set of follow-up questions were sent to additional specialists in all the companies to further gather and clarify experiences on the topics. After completing the data collection, analyses were conducted across each company to obtain a comprehensive understanding of the SCC practices. The involved researchers took part in verifying the results to avoid any misinterpretations.

\begin{tabular}{|c|c|c|c|c|c|c|}
\hline Company & $\begin{array}{l}\text { Company type and } \\
\text { size (according to } \\
\text { EU definition) }\end{array}$ & $\begin{array}{l}\text { Product } \\
\text { type }\end{array}$ & $\begin{array}{l}\text { Business } \\
\text { type }\end{array}$ & Interviews & Informants & Role of the informants \\
\hline A & $\begin{array}{l}\text { Manufacture of } \\
\text { electronic products } \\
\text { Medium }\end{array}$ & $\begin{array}{l}\text { Tangible \& } \\
\text { intangible }\end{array}$ & $\begin{array}{l}\text { B2C } \\
\text { B2B }\end{array}$ & 2 interviews & 4 & $\begin{array}{ll}\text { - } & \text { R\&D manager } \\
\text { - } & \text { SM specialist } \\
\text { - } & \text { After sales manager } \\
\text { - Supporting tasks } \\
\text { manager }\end{array}$ \\
\hline B & $\begin{array}{l}\text { Manufacture of } \\
\text { chemical products } \\
\text { Large }\end{array}$ & Tangible & B2B & 1 interview & 2 & $\begin{array}{l}\text { - R\&D, global processes } \\
\text { and projects director } \\
\text { - Supply-chain manager }\end{array}$ \\
\hline $\mathrm{C}$ & $\begin{array}{l}\text { Manufacture of } \\
\text { medical instruments } \\
\text { \& supplies } \\
\text { Medium }\end{array}$ & Tangible & B2B & 2 interviews & 3 & $\begin{array}{l}\text { - Chief operations } \\
\text { officer } \\
\text { - Logistics manager } \\
\text { - Supply-chain manager }\end{array}$ \\
\hline $\mathrm{D}$ & $\begin{array}{l}\text { Manufacture of } \\
\text { medical instruments } \\
\text { \& supplies } \\
\text { Large }\end{array}$ & $\begin{array}{l}\text { Tangible \& } \\
\text { intangible }\end{array}$ & $\mathrm{B} 2 \mathrm{~B}$ & 2 interviews & 3 & $\begin{array}{l}\text { - R\&D manager } \\
\text { - Logistics manager } \\
\text { - Production manager }\end{array}$ \\
\hline $\mathrm{E}$ & $\begin{array}{c}\text { Manufacture of } \\
\text { consumer electronics } \\
\text { Large }\end{array}$ & $\begin{array}{l}\text { Tangible \& } \\
\text { intangible }\end{array}$ & B2C & 2 interviews & 4 & $\begin{array}{l}\text { - Logistics manager } \\
\text { - Demand/supply } \\
\text { manager } \\
\text { - R\&D director } \\
\text { - SM director }\end{array}$ \\
\hline $\mathrm{F}$ & $\begin{array}{l}\text { Manufacture of } \\
\text { communication } \\
\text { equipment } \\
\text { Small }\end{array}$ & $\begin{array}{l}\text { Tangible \& } \\
\text { intangible }\end{array}$ & B2C & 2 interviews & 3 & $\begin{array}{l}\text { - } \text { SM specialist } \\
\text { - } \text { R\&D manager } \\
\text { - } \text { Board member }\end{array}$ \\
\hline
\end{tabular}

Table 1. Analysed companies' information and interviews characteristics 


\subsection{Companies and the Context for SCC}

The company A outsources its manufacturing to an electronic manufacturing services (EMS) provider that is selected during the NPD. The company strives to use standard components to ensure better availability, simplify the product development and decrease the costs. The EMS partner has a certain freedom in selecting the components, but for important parts, the company makes the decision. The EMS manufacturer is responsible for the operational purchasing of the electronic components and supplier contracts, while company A handles the product-specific parts.

Company B utilises its manufacturing plants located around the world as well as contract manufacturers. The global and cross-functional supply-chain planning and cooperation are done to balance supply and demand and to optimise the utilisation of company assets. The sourcing team works in a role of SM and plans the supply activities and ensures an uninterrupted materials flow, utilisation of the best suppliers and adequate capacity. The company closely collaborates with their suppliers on the operational and strategic level.

Company $\mathrm{C}$ utilises EMS manufacturers to produce their goods and to deal with the supply management. The company forecasts the demand for few upcoming months, which the EMS factory utilises to deal with purchasing, supply planning, logistics and product manufacturing. The company is currently ramping up the production with a new EMS factory.

Company D utilises its manufacturing capabilities. Supply-chain management is divided into mass production and product customisation for specific customer needs. The modular structure of the products and the standardised supply-chain process ensure the efficiency and flexibility of the supply, production and logistics. The supply-chain process owners define the process descriptions, key performance indicators and targets to analyse and develop the whole supply-chain process. The company frequently collaborates and meets with its main suppliers.

Company E manufactures its products in its factories. The supply-chain processes are clear and organised worldwide. Global sourcing takes care of supply activities, including supplier, material and component selection. Sourcing challenges include extensive supplier selection, sudden changes in volumes or natural disasters. The supplier location is seen important and suppliers of custom-made components are usually located close the factories to improve the delivery accuracy, the communication and the suitability of the parts according to the requirements.

Company $\mathrm{F}$ outsources the production and testing of their products to a contract manufacturer $(\mathrm{CM})$. At the end of the NPD, the company produces the first batches before transferring the production to the $\mathrm{CM}$. The company measures the contractor's delivery reliability and product quality. Supply activities are 
not accomplished systematically as a process, one specialist handles all the SM related activities, and no related targets or metrics are regularly monitored. The sourcing is done based on a yearly plan as the company operates in a season-based market.

\section{Analysis and Results}

\subsection{Analysis of the Supply Capability Creation Characteristics}

This section discusses the supply capability creation characteristics in the context of the analysed companies. The following six characteristics are based on the RQ1 outcome.

\section{(1) Integrated NPD - early supply specialists involvement during the NPD}

All the companies utilise cross-functional NPD teams and involve various departments and specialists during the NPD projects. In the cases A and E, however, the involvement of the multiple stakeholders is not formal, and the integration to NPD could be done more systematically. Stakeholders as hardware, software, sales, marketing, supply-chain management and supply management specialists are included in every company's NPD. The cross-functional NPD team is recognised to be helpful in making products and their commercialisation more successful. However, representatives of company D mention that the agility of the NPD process is also crucial, as the type of NPD projects varies considerably. An informant from company B stated that "the early involvement of relevant stakeholders and excellent communication between cross-functional teams during the whole duration of the project is necessary to create products better, cheaper and faster."

Finding 1. Integrated NPD and early involvement of cross-functional specialist are necessary for effective and efficient product creation.

\section{(2) NPD process description}

The NPD process is described formally by every company, except for company $F$ where it is not formally mapped. All the companies utilise an adjusted NPD process based on the stage-gate model with typical phases (feasibility study, project planning, concept development, development and integration, piloting and ramp-up). The NPD process of the company B varies depending on the project scope and goals (e.g. some stages may be left out or combined for small enhancement type of product development). Company $\mathrm{D}$ rarely launches completely new products and the development is conducted by enhancing existing products. Due to long and mandatory testing phase by an external organisation, the ramp-up phase is accomplished in parallel to testing. In company E, 
the teams work concurrently, and engineering outcomes are synchronised according to the NPD gate process.

Finding 2. NPD process description supports reaching company project goals, including launching new products and carrying out product enhancements.

\section{(3) Milestone criteria for NPD process}

Companies A, B, C, E utilise milestone criteria at the gates of their NPD processes. Depending on the milestone, different boards, teams and specialists review the status of the NPD project from its beginning to its end. In company B, NPD projects are reviewed to ensure that the product is profitable, manufacturable, safe, and fits the company strategy. In company A, milestone's checklist tasks - consisting of reports done, tests executed, or certain items taken into consideration in the plans - must be implemented before entering into the next stage of the NPD. In company $\mathrm{C}$, the review can also be done between the milestones; sub-areas, such hardware and software can be accepted before the whole milestone is approved. The required tasks and targets for each milestone are documented and listed, and all the required activities should be completed before a certain milestone can be approved. Concerning the companies D and F, standard and systematic milestones criteria between the NPD phases do not exist. An informant from company F mentioned, "those issues cause ambiguous steps, increase the responsibilities of the team members and lead to challenges in supervising and leading the NPD project". In company $\mathrm{D}$, the business unit manager is responsible for go/kill decisions but projects are rarely terminated. The gates are not formally conducted, but the senior management is deeply involved in the product development and can prioritise or put on hold the NPD projects.

Finding 3. Milestone criteria at NPD process gates support managing and monitoring projects, but can lead to challenges when excessive.

\section{(4) SCC related activities implemented during the NPD process}

All the case companies implement some SCCC/SCC activities alongside the NPD process in a reactive way, except for company $\mathrm{E}$ where they are accomplished in a proactive way already in the early phases of the NPD. Every firm involves the supply-chain representatives in the NPD process to accomplish all the related supply-chain activities and to ensure the ramp-up of new products. In cases of $\mathrm{B}, \mathrm{C}, \mathrm{E}$, specialists are nominated to play the main role and to be the key coordinator in accomplishing the SCCC activities and ensuring smooth ramp-ups. In company B, the product manager approves, for example, the product composition, its production location and the way of manufacturing. In company $\mathrm{C}$, the ramp-up manager is responsible for SCCC and consults different 
supply-chain members to guarantee the SCCC at the end of the product development project. In company E, the stakeholders of SCCC (the NPD team, the project manager, and the designers) work together to accomplish the SCCC activities according to the business plan and volume estimations. In company F, the SCC is the primary focus of SCCC and the sourcing manager is the most important person involved in these activities. Company D does not nominate an SCCC manager or specialist to lead the SCCC. No company nominates process owners for the SCCC subprocess and related sub-activities (such as logistics or supply capability creation).

Company C employs some SCCC related tasks, targets and documents such as the evaluation of potential production sites, production planning, product process flow creation, manufacturing planning, or production verification. In company D, the SCCC and SCC take place at the piloting and testing phases. In the case of E, at the early phases of NPD, the preliminary guidelines for demand-supply planning, sourcing, production and logistics are defined. Possible new technologies, suppliers' capabilities, tooling, manufacturing capabilities and other related aspects are taken into account during the NPD process. Only parts of SCCC are accomplished in company F but not created systematically. The company strives to organise SCCC activities alongside the product development, but the lack of specified processes and guidelines make it rather ineffective. Every company have limited SCC activities alongside the NPD, even though some tasks, targets and documents exist. However, the SCC is done proactively at early NPD phases in company E. Supply Management gets involved and cooperates already during the first stage of the NPD to ensure the availability of materials during the NPD, and later for the mass production.

Finding 4. SCCC/SCC activities alongside NPD process, reactive or proactive are necessary for efficient ramp-up of new products.

\section{(5) Milestone criteria for SCCC and SCC process}

No company possesses milestone criteria for SCCC/SCC process. The company C has started to outline the supply-chain key events into the milestone path, but this work is still at the very beginning. In company A, B, D, F the SCCC activities are not systematically described, measured, managed and implemented as a separate subprocess of NPD process. The SCCC steps are not clear or documented to prepare the supply-chain for the new ramp-ups. However, an informant from company $\mathrm{E}$ mentioned that "the SCCC has an important role in the NPD in minimising the time-to-market, following the schedule, and effectively reacting to market changes and varying sales forecasts."

Finding 5. The significance of milestone criteria for SCCC and SCC process is recognised, but not widely implemented. 


\section{(6) Select, qualify and contract suppliers and material on time along the NPD process}

In company $\mathrm{A}$, the product components and related suppliers are reviewed and selected as early as possible during the NPD process by the EMS manufacturer and the case company. A substitute list of components and suppliers are made if any issues appear later during the product development. During the prototype building phase, either the product manager or the sourcing manager are responsible for the material orders. In company $\mathrm{B}$, one of the key activity to ensure efficient ramp-up is defining raw material availability and sourcing for a new product. These SCC activities are done in the early stages of the development projects and then updated and adjusted until the product ramp-up phase. The product manager collaborates with SM specialists, follows up the SCC activities and makes sure the raw materials are available on time. In company C, some SCC related tasks, targets and documents exist. During the first NPD phase, the potential subcontractors for the program are listed, the evaluation of potential suppliers is started, the component samples are ordered and the critical sourcing components are listed. During the second phase, long lead-time components are ordered, and later, the overall supply process is prepared for ramp-up. In company $\mathrm{D}$, during the development and integration stage, the NPD project manager starts the discussion and negotiation with the suppliers. Local suppliers are preferred to ensure effective information sharing. The suppliers' offerings are tested, and the integration of the product's design is evaluated. The suppliers' capabilities and methods are taken into account in the design phase. The rest of the SCC is done during the testing/ramp-up phase. In company E, SM cooperates with the demand-supply planning team to estimate the volumes and to forecast the needed capacity. Additionally, the SM is involved in formulating the business plan during the NPD concept phase as well as being responsible for material cost calculations and negotiations with suppliers. In company F, as early as possible during the NPD, the sourcing manager is responsible for sourcing all the components, examining the contract manufacturers or selecting the suppliers for the mechanical parts. The sourcing of long lead-time components is started as early as possible so that the development and prototyping phase would not be delayed.

Finding 6. Selecting, qualifying and contracting suppliers and material on time along the NPD process has significance for product success. 


\subsection{Cross-case Analysis Synthesis}

Based on the previous section 4.1, this part presents the synthesis of the cross-case analysis to compare the supply capability creation practices in the six analysed companies. The usage of the characteristics of SCC varied in the companies - the individual aspects are presented in Table 2.

\begin{tabular}{|c|c|c|c|c|c|c|}
\hline & A & B & $\mathrm{C}$ & $\mathrm{D}$ & $\mathrm{E}$ & F \\
\hline 1. Integrated NPD - early supply specialists involvement during the NPD & $\mathrm{O}$ & $\mathrm{X}$ & $\mathrm{X}$ & $\mathrm{X}$ & $\mathrm{X}$ & $\mathrm{O}$ \\
\hline 2. NPD process description & $\mathrm{X}$ & $\mathrm{X}$ & $\mathrm{X}$ & $\mathrm{X}$ & $\mathrm{X}$ & $\mathrm{O}$ \\
\hline 3. Milestone criteria for NPD process & $\mathrm{X}$ & $\mathrm{X}$ & $\mathrm{X}$ & - & $\mathrm{X}$ & - \\
\hline 4. SCC related activities implemented during the NPD process & $\mathrm{O}$ & $\mathrm{O}$ & $\mathrm{O}$ & $\mathrm{O}$ & $\mathrm{X}$ & $\mathrm{O}$ \\
\hline 5. Milestone criteria for SCCC and SCC process & - & - & - & - & - & - \\
\hline 6. Select, qualify and contract suppliers and material on time along the NPD process & $\mathrm{O}$ & $\mathrm{O}$ & $\mathrm{O}$ & $\mathrm{O}$ & $\mathrm{X}$ & $\mathrm{O}$ \\
\hline
\end{tabular}

$\mathrm{X}=$ applies to the organisation

$-=$ does not apply to the organisation

$\mathrm{O}=$ somewhat applies to the organisation

Table 2. Characteristics of SCC identified in the case companies

The analysed companies understand the value of an organised, described and integrated NPD. All the companies have a description of their NPD process (although the company F does not map it formally) and every company somehow involve specialists who are not related to the product engineering itself (such as marketing, supply-chain and supply specialists). However, not every organisation utilises milestone criteria during the NPD process (D and F do not implement formal review). Even though none possesses an SCCC process nor the underlying SCC process, some SCC activities are implemented alongside the NPD (case E being the most advanced in this exercise). Finally, all the companies strive to select, qualify and contract suppliers and materials promptly during the NPD process but none, expect the company E, do it systematically. Although the case company D has reasons in not adopting a milestone-driven NPD, SCCC and SCC process (due to specific business environment), all the informants consider the proactive management of SCC activities and the use of a mapped process to prepare the supply readiness valuable and beneficial. Therefore, an SCC process - including activities and milestones criteria - is proposed in the next section. 


\section{Supply Capability Creation Process}

Based on the literature, the analysis of the current practices of six companies and the cross-case analysis, a systematic SCC process is established as a part of the SCCC and NPD process (RQ3). The SCCC process, consisting of supply, production and logistics capability creation, should be described in detail, including what activities need to be done and by whom during each phase of the project. The instruction set is integrated and followed in parallel with the NPD process (milestone-driven process adapted from Cooper, 2001; Ulrich and Eppinger, 2008). The SCCC process also specifies the criteria to be met for each milestone so that the project can move to the next phase. Figure 2 illustrates the link between the generic NPD and the respective SCCC process milestones criteria.

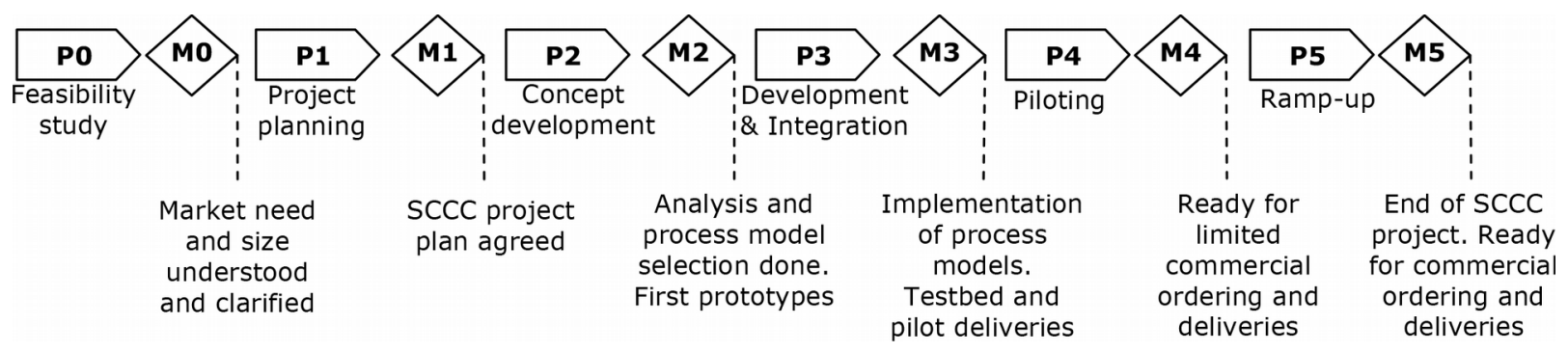

Figure 2. Overall SCCC milestone criteria aligned with the adapted NPD process

The outcome of this article focuses to the SCC consisting of key activities and milestone criteria to create the supply capability creation process. The created SCC process (Table 3) covers all stages from P0 (feasibility study) to P5 (launch) including the main activities to meet the proposed milestone criteria. Depending on the size of the company and the nature of the NPD project, a nominated SCC manager or a general SCCC manager is part of the NPD team and will be responsible for the SCC activities. 


\begin{tabular}{|c|c|c|}
\hline $\begin{array}{l}\text { Phase P0 } \\
\text { Feasibility } \\
\text { Study }\end{array}$ & $\begin{array}{l}\text { SCC } \\
\text { activities }\end{array}$ & $\begin{array}{l}\text { Establish the SCC team. Inform the SM staff of the upcoming product development. } \\
\text { Clarify the supplier base, the preferred/strategic suppliers and components. } \\
\text { Inform the NPD team of the possible long lead-time materials } \\
\text { Screen the new technologies and materials from the preferred suppliers (technologies } \\
\text { being mature from the supplier point-of-view but new by the focal company) }\end{array}$ \\
\hline $\begin{array}{l}\text { Market need and } \\
\text { size clarified, } \\
\text { process models } \\
\text { selected }\end{array}$ & $\begin{array}{l}\text { Milestone } \\
\text { criteria }\end{array}$ & $\begin{array}{l}\text { SCC team established. } \\
\text { Current supply capabilities clarified. SCC targets are pre-established. } \\
\text { Preferred suppliers and components identified. }\end{array}$ \\
\hline \multirow{2}{*}{$\begin{array}{l}\text { Phase P1 } \\
\text { Project } \\
\text { Planning } \\
\text { SCCC project plan } \\
\text { agreed and started }\end{array}$} & $\begin{array}{l}\text { SCC } \\
\text { activities }\end{array}$ & $\begin{array}{l}\text { Create the SCC plan. } \\
\text { Select the preferred supply models for the different types of supply according to the } \\
\text { company's supply strategy. } \\
\text { Qualification and agreement of critical suppliers. Set the targets for the total cost of } \\
\text { ownership of the purchased materials and items. }\end{array}$ \\
\hline & $\begin{array}{l}\text { Milestone } \\
\text { criteria }\end{array}$ & $\begin{array}{l}\text { SCC plan created and approved as a part of SCCC plan. } \\
\text { Supply models selected. SCC targets are agreed. } \\
\text { The critical suppliers have been qualified and agreed. }\end{array}$ \\
\hline \multirow{2}{*}{$\begin{array}{l}\text { Phase P2 } \\
\text { Concept } \\
\text { Development } \\
\text { Testing process } \\
\text { models, make first } \\
\text { prototypes }\end{array}$} & $\begin{array}{l}\text { SCC } \\
\text { activities }\end{array}$ & $\begin{array}{l}\text { Identify the items to be supplied (e.g. raw materials, auxiliary materials, wearing parts, } \\
\text { tools and packing material). Identify and examine the supply market. } \\
\text { Identify, evaluate and update the existing suppliers and contracts. } \\
\text { Evaluate the new suppliers and contracts and select the most suitable suppliers. } \\
\text { Evaluate the total cost of ownership of the material and items. } \\
\text { Begin the supply of long-lead time components and tooling. }\end{array}$ \\
\hline & $\begin{array}{l}\text { Milestone } \\
\text { criteria }\end{array}$ & $\begin{array}{l}\text { All the items to be supplied are pre-identified. } \\
\text { Agreement discussions with the potential suppliers started }\end{array}$ \\
\hline \multirow{2}{*}{$\begin{array}{l}\text { Phase P3 } \\
\text { Development and } \\
\text { Integration } \\
\text { Implement process } \\
\text { models, pilot } \\
\text { deliveries }\end{array}$} & $\begin{array}{l}\text { SCC } \\
\text { activities }\end{array}$ & $\begin{array}{l}\text { Establish new suppliers and contracts in accordance with the supplier strategy. } \\
\text { Finalise the list of the supplied items as well as the related supply base. } \\
\text { Implement the supply models for all the supplied items. }\end{array}$ \\
\hline & $\begin{array}{l}\text { Milestone } \\
\text { criteria }\end{array}$ & All the related suppliers are contracted, and purchase prices are agreed. \\
\hline \multirow{2}{*}{$\begin{array}{l}\text { Phase P4 } \\
\text { Piloting (Testing } \\
\text { and Validation) } \\
\text { Ready for limited } \\
\text { commercial } \\
\text { deliveries }\end{array}$} & $\begin{array}{l}\text { SCC } \\
\text { activities }\end{array}$ & $\begin{array}{l}\text { Ensure all the involved suppliers are aware and ready for the expected business and } \\
\text { the objectives from the incoming product. Set backup plans. } \\
\text { Establish the payment process for the supplied material and items. } \\
\text { Pilot and validate the supply models for all the supplied items. } \\
\text { Optimise and fine-tune the SM capability. } \\
\text { Establish supplier relationships and supplier performance management. }\end{array}$ \\
\hline & $\begin{array}{l}\text { Milestone } \\
\text { criteria }\end{array}$ & $\begin{array}{l}\text { All the suppliers are established and ready to supply every needed item in the right } \\
\text { condition and according to specifications. } \\
\text { The supply models are validated and meet the quality, time and cost targets. } \\
\text { The SM and supply process workforce is trained. } \\
\text { Supply process is piloted, ready for product ramp-up and any inconveniences. }\end{array}$ \\
\hline \multirow{2}{*}{$\begin{array}{l}\text { Phase P5 } \\
\text { Ramp-up (Launch) } \\
\text { Ready for } \\
\text { commercial } \\
\text { deliveries. End of } \\
\text { SCCC project }\end{array}$} & $\begin{array}{l}\text { SCC } \\
\text { activities }\end{array}$ & $\begin{array}{l}\text { Manage and facilitate suppliers ramp-up and improve collaboration } \\
\text { Establish regular and mass volume supply and SM capabilities. } \\
\text { Document the best practices and lessons learned during the SCCC project. } \\
\text { Transfer all the SCC responsibilities to the SM organisation. } \\
\text { Disassemble the SCC team. }\end{array}$ \\
\hline & $\begin{array}{l}\text { Milestone } \\
\text { criteria }\end{array}$ & $\begin{array}{l}\text { Supply process is ready for mass volumes. } \\
\text { Supply responsibility is handed over to the operational SM organisation. } \\
\text { The SCC team is disassembled. }\end{array}$ \\
\hline
\end{tabular}

Table 3. SCC process: key activities and milestone criteria 
Firstly, the supply process should be defined precisely, along with the related process owners, requirements, targets and metrics. Secondly, the NPD process and governance should be characterised to govern and monitor the product development activities and its progression. Implementing gates to NPD process is an important enabler to building systematic and proactive SCCC and SCC processes. The systematic process for SCCC - including SCC - can then be created and integrated as a part of the NPD process. Accordingly, clear SCCC and SCC roles, responsibilities, activities and milestones can be created. SCC metrics and targets - aligned with the related supply process - should also be established and monitored.

The SCC needs to be planned and managed from the beginning of the NPD. SCC supports the SM by identifying the need for right materials and suppliers at the appropriate time during NPD, thus supporting an optimal stock value and limiting delays. An effective and efficient SCC process can help to achieve lowcost, qualified supplier network and materials for successful product ramp-ups and operational supply process. The SCC process defines how and when the potential new suppliers and materials should be selected, qualified and contracted during the NPD process. Utilising qualified and contracted suppliers may guarantee appropriate reliability and quality supplies. Other issues to be taken into account during the SCC process are related to the supplier agreement schedule, long lead-time components and tooling as well as the deadlines for testing and qualifying new materials.

\section{Discussion and Conclusions}

The efficient and smooth delivery of new products is highly influenced by the early supply-chain capability creation (SCCC) activities within the new product development (NPD) process. The SCCC, consisting of supply, production and logistics capability creation, has to be created in line with the product development process to avoid any operational delivery challenges at product ramp-up phase and beyond. This article focuses on the supply capability creation (SCC) by analysing earlier research and empirically six companies. This paper introduces an SCC process that has not been presented previously in the literature. This process outlines the main SCC activities and milestone criteria in preparing the supply process for new products. The main goal of SCC is to establish qualified and contracted suppliers and materials at the right moment along the NPD process, ultimately at the product ramp-up phase. Only products, with well-established SCC, can be handed over to operational supply process and supply management teams.

The scientific implications of this study include introducing the supply capability creation process within the NDP process. This article provides original contribution as only a few researchers have previously addressed the coordination of SC and NPD (Carrillo \& Franza, 2006; Van Hoek \& 
Chapman, 2007, Hilletofth et al., 2010; Hillebrand \& Biemans 2004; Pero et al., 2010; Marsillac \& Roh, 2014). Nevertheless, the earlier research has separately covered the business processes involving NPD (Cooper, 2001; Ulrich \& Eppinger, 2008; Liker 2004) and SC (Su \& Gargeya, 2012; Cheng et al., 2010). The need for the better integration of NPD and SC processes in the product development phase has, however, been identified before (Van Hoek \& Chapman, 2007). Compared to the earlier extensive literature on supplier involvement and its potential benefits on the NPD, relatively limited number of studies has been done on the SM role in NPD (Luzzini et al., 2015). The new contribution is provided as an SCC process to prepare the operational supply process during the NPD, not directly focusing on supplier involvement in NPD nor influencing the product design.

Managerial implications include a variety of companies potentially benefitting of the research outcome in introducing and promoting the importance of the SCCC, and specifically, the SCC process to prepare the supply capability systematically within the NPD. The study will benefit the SM and NPD organisations by ensuring successful product ramp-ups based on the systematic NPD, SCCC and underlying SCC processes, crucial for delivering new products to the customers at the targeted time. The systematic description of the SCCC process and underlying SCC process can serve as a basis for aligning the NPD and SC processes. The proposed main SCC activities involve the systematic qualification and contracting of the required suppliers and materials early enough during the NPD process. The article may support the understanding of the importance of early involvement of competent SM resources to influence the product design and to prepare the supply readiness for smooth product ramp-ups. Managers may also gain support for understanding how crucial these considerations can be from the overall product performance over the life cycle. Managers must understand that the SCC process needs to be developed by a nominated SCC process owner as an integral part of the NPD process and its development team. The SCC process should be executed by a nominated SCC manager within all NPD projects. The SCC manager needs to involve members from the operational SM function - at the right moment - to prepare the supply process for new products ramp-ups. It is worth noting that the SCCC and SCC process can and should be adjusted according to the company size, the supply-chain model, the product characteristics and the type of product development.

The limitations of this study include analysing a limited number of companies, while a deeper analysis would potentially increase the validity of the current findings. The consistency of the findings might also vary if a larger number and different types of companies from diverse industries would be included. The study is more conforming to tangible products, and a similar research on intangible products might deviate from the current findings. One limitation involves the level of detail for the activities and milestone criteria listed in the SCC process. Based on these limitations and the results of the study, some recommendations may be given for future research. It would be 
interesting to carry out investigations regarding the actual impact of performing the SCC process as proposed. Additionally, this article only focuses on the supply capability creation part, further research for other SCCC sub-processes such as production capability creation and logistics capability creation would be valuable.

\section{References}

Ahmed, P.K, \& Rafiq, M. (2002). Internal Marketing: Tools and Concepts for Customer Focused Management. Oxford: Butterworth-Heinemann. https://doi.org/10.1016/B978-0-7506-4838-7.50006-5

Almgren, H. (1999). Towards a framework for analyzing efficiency during start-up: An empirical investigation of a Swedish auto manufacturer. International Journal of Production Economics, 60, 79-86. https://doi.org/10.1016/S0925-5273(98)00189-3

Anthony, M.T., \& McKay, J. (1992). From experience: balancing the product development process: achieving product and cycle-time excellence in high-technology industries. Journal of Product Innovation Management, 9(2), 140-147. https://doi.org/10.1016/0737-6782(92)90005-W

Ball, P.D., Roberts, S., Natalicchio, A., \& Scorzafave, C. (2011). Modelling production ramp-up of engineering products. Proceedings of the Institution of Mechanical Engineers, Part B: Journal of Engineering Manufacture, 225(6), 959-971. https://doi.org/10.1177/09544054JEM2071

Barczak, G., \& Kahn, K.B. (2012). Identifying new product development best practice. Business horizons, 55(3), 293-305. https://doi.org/10.1016/j.bushor.2012.01.006

Barczak, G., Griffin, A., \& Kahn, K.B. (2009). Perspective: trends and drivers of success in NPD practices: results of the 2003 PDMA best practices study. Journal of product innovation management, 26(1), 3-23. https://doi.org/10.1111/j.1540-5885.2009.00331.x

Barczak, G., Kahn, K.B., \& Moss, R. (2006). An exploratory investigation of NPD practices in nonprofit organizations. Journal of Product Innovation Management, 23(6), 512-527. https://doi.org/10.1111/j.15405885.2006.00221.x

Behncke, F.G., Eichinger, J., \& Lindemann, U. (2014). Involvement of Procurement in the Product Creation Process: A Systematization Scheme of Measures. Procedia CIRP, 17, 356-361. https://doi.org/10.1016/j.procir.2014.01.078

Bernard, A., \& Fischer, A. (2002). New trends in rapid product development. CIRP Annals-Manufacturing Technology, 51(2), 635-652. https://doi.org/10.1016/S0007-8506(07)61704-1 
Bhuiyan, N. (2011). A framework for successful new product development. Journal of Industrial Engineering and Management, 4(4), 746-770. https://doi.org/10.3926/jiem.334

Brewer, B., \& Arnette, A.N. (2017). Design for procurement: What procurement driven design initiatives result in environmental and economic performance improvement? Journal of Purchasing and Supply Management, 23(1), 28-39. https://doi.org/10.1016/j.pursup.2016.06.003

Brewer, B.L., Ashenbaum, B., \& Carter, J.R. (2013). Understanding the supply chain outsourcing cascade: when does procurement follow manufacturing out the door? Journal of Supply Chain Management, 49(3), 90-110. https://doi.org/10.1111/jscm.12021

Burt, D.N., \& Pinkerton, R.L. (1996) A Purchasing Manager's Guide to Strategic Proactive Procurement, New York, NY: AMACOM Books.

Caniato, F., \& Größler, A. (2015). The moderating effect of product complexity on new product development and supply chain management integration. Production Planning \& Control, 26(16), 1306-1317. https://doi.org/10.1080/09537287.2015.1027318

Carr, A.S., Kaynak, H., Hartley, J.L., \& Ross, A. (2008). Supplier dependence: impact on supplier's participation and performance. International Journal of Operations \& Production Management, 28(9), 899-916. https://doi.org/10.1108/01443570810895302

Carrillo, J.E., \& Franza, R.M. (2006). Investing in product development and production capabilities: The crucial linkage between time-to-market and ramp-up time. European Journal of Operational Research, 171(2), 536-556. https://doi.org/10.1016/j.ejor.2004.08.040

Chen, J., Damanpour, F., \& Reilly, R.R. (2010). Understanding antecedents of new product development speed: A meta-analysis. Journal of Operations Management, 28(1), 17-33.

https://doi.org/10.1016/j.jom.2009.07.001

Chen, J., Reilly, R.R., \& Lynn, G.S. (2005). The impacts of speed-to-market on new product success: the moderating effects of uncertainty. IEEE Transactions on engineering management, 52(2), 199-212. https://doi.org/10.1109/TEM.2005.844926

Cheng, Y., Skov Madsen, E., \& Liangsiri, J. (2010). Transferring knowledge in the relocation of manufacturing units. Strategic Outsourcing: An International Journal, 3(1), 5-19.

https://doi.org/10.1108/17538291011023043

Choi, T.Y., \& Krause, D.R. (2006). The supply base and its complexity: Implications for transaction costs, risks, responsiveness, and innovation. Journal of Operations Management, 24(5), 637-652.

https://doi.org/10.1016/j.jom.2005.07.002 
Cooper, R.G. (2001). Winning at new products - Accelerating the process from idea to launch. 3rd ed. Cambridge: Perseus Publishing.

Cooper, R.G., Edgett, S.J., \& Kleinschmidt, E.J. (2004). Benchmarking best NPD practices-III. Research-Technology Management, 47(6), 43-55.

Dobler, D.W., \& Burt, D.N. (1996) Purchasing and Supply Management. New York: McGraw-Hill.

Dereli, T., Baykasoglu, A., \& Buyukozkan, G. (2008). An affordable reverse engineering framework for innovative rapid product development. International Journal of Industrial and Systems Engineering, 3(1), 31-37. https://doi.org/10.1504/IJISE.2008.015912

Eisenhardt, K.M. (1989). Building theories from case study research. Academy of management review, 14(4), 532-550. https://doi.org/10.5465/AMR.1989.4308385

Ellram, L.M., \& Carr, A. (1994). Strategic purchasing: a history and review of the literature. Journal of Supply Chain Management, 30(1), 9-19. https://doi.org/10.1111/j.1745-493X.1994.tb00185.x

Elstner, S., \& Krause, D. (2014). Methodical approach for consideration of ramp-up risks in the product development of complex products. Procedia CIRP, 20, 20-25. https://doi.org/10.1016/j.procir.2014.05.027

Gebauer, J., \& Scharl, A. (1999). Between flexibility and automation: an evaluation of web technology from a business process perspective. Journal of Computer-Mediated Communication, 5(2). https://doi.org/10.1111/j.1083-6101.1999.tb00340.x

Gehani, R.R. (1992). Concurrent product development for fast-track corporations. Long Range Planning, 25(6), 40-47. https://doi.org/10.1016/0024-6301(92)90168-2

Goffin, K., Szwejczewski, M., \& New, C. (1997). Managing suppliers: when fewer can mean more. International Journal of Physical Distribution \& Logistics Management, 27(7), 422-436.

https://doi.org/10.1108/09600039710188486

Goodchild, A., Herring, C., \& Milosevic, Z. (2000) Business contracts for B2B. Proceedings of the CAISE'00 Workshop on Infrastructure for Dynamic Business-to-Business Service Outsourcing, Stockholm (SWEDEN), 5-6 June, 2000.

Grieger, M. (2003). Electronic marketplaces: A literature review and a call for supply chain management research. European journal of operational research, 144(2), 280-294. https://doi.org/10.1016/S0377-2217(02)003946

Haller, M., Peikert, A., \& Thoma, J. (2003). Cycle time management during production ramp-up. Robotics and Computer-Integrated Manufacturing, 19(1), 183-188. https://doi.org/10.1016/S0736-5845(02)00078-9 
Hillebrand, B., \& Biemans, W.G. (2004). Links between internal and external cooperation in product development: an exploratory study. Journal of Product Innovation Management, 21(2), 110-122. https://doi.org/10.1111/j.0737-6782.2004.00061.x

Hilletofth, P., Ericsson, D., \& Lumsden, K. (2010). Coordinating new product development and supply chain management. International Journal of Value Chain Management, 4(1-2), 170-192. https://doi.org/10.1504/IJVCM.2010.031808

Hüntelmann, J., Reinsch, S., \& Märtens, A. (2007). Logistic-and cost-oriented cross-company ramp-up planning. In Digital Enterprise Technology (pp. 115-122). Springer US. https://doi.org/10.1007/978-0-387-49864$5 \_13$

Jack, E.P., \& Powers, T.L. (2015). Managing strategic supplier relationships: antecedents and outcomes. Journal of Business \& Industrial Marketing, 30(2), 129-138. https://doi.org/10.1108/JBIM-08-2011-0101

Kärkkäinen, H., Piippo, P., \& Tuominen, M. (2001). Ten tools for customer-driven product development in industrial companies. International journal of production economics, 69(2), 161-176.

https://doi.org/10.1016/S0925-5273(00)00030-X

Kahn, K.B., Barczak, G., Nicholas, J., Ledwith, A., \& Perks, H. (2012). An examination of new product development best practice. Journal of Product Innovation Management, 29(2), https://doi.org/10.1111/j.15405885.2011.00888.x

Kim, J.I., \& Shunk, D.L. (2004). Matching indirect procurement process with different B2B e-procurement systems. Computers in Industry, 53(2), 153-164. https://doi.org/10.1016/j.compind.2003.07.002

Kim, S.W. (2006). The effect of supply chain integration on the alignment between corporate competitive capability and supply chain operational capability. International Journal of Operations \& Production Management, 26(10), 1084-1107. https://doi.org/10.1108/01443570610691085

Koufteros, X.A., Vonderembse, M.A., \& Doll, W.J. (2002). Integrated product development practices and competitive capabilities: the effects of uncertainty, equivocality, and platform strategy. Journal of Operations Management, 20(4), 331-355. https://doi.org/10.1016/S0272-6963(02)00018-9

Kraut, R., Steinfield, C., Chan, A., Butler, B., \& Hoag, A. (1998). Coordination and virtualization: The role of electronic networks and personal relationships. Journal of Computer-Mediated Communication, 3(4). https://doi.org/10.1111/j.1083-6101.1998.tb00084.x

Lakemond, N., Echtelt, F., \& Wynstra, F. (2001). A configuration typology for involving purchasing specialists in product development. Journal of Supply Chain Management, 37(3), 11-20.

https://doi.org/10.1111/j.1745-493X.2001.tb00108.x 
Liker, J. (2004). Toyota Way. New York: McGraw-Hill.

Lindemann, M.A., \& Schmid, B.F. (1998). Framework for specifying, building, and operating electronic markets. International Journal of Electronic Commerce, 3(2), 7-21. https://doi.org/10.1080/10864415.1998.11518331

Lummus, R.R., \& Vokurka, R.J. (1999). Defining supply chain management: a historical perspective and practical guidelines. Industrial Management \& Data Systems, 99(1), 11-17.

https://doi.org/10.1108/02635579910243851

Luzzini, D., Amann, M., Caniato, F., Essig, M., \& Ronchi, S. (2015). The path of innovation: purchasing and supplier involvement into new product development. Industrial Marketing Management, 47, 109-120. https://doi.org/10.1016/j.indmarman.2015.02.034

Marsillac, E., \& Roh, J.J. (2014). Connecting product design, process and supply chain decisions to strengthen global supply chain capabilities. International Journal of Production Economics, 147, 317-329. https://doi.org/10.1016/j.ijpe.2013.04.011

McGinnis, M.A., \& Vallopra, R.M. (1999). Purchasing and supplier involvement: issues and insights regarding new product success. Journal of Supply Chain Management, 35(2). https://doi.org/10.1111/j.1745493X.1999.tb00057.x

McIvor, R., Humphreys, P., \& Cadden, T. (2006). Supplier involvement in product development in the electronics industry: a case study. Journal of Engineering and Technology Management, 23(4), 374-397. https://doi.org/10.1016/j.jengtecman.2006.08.006

Minderhoud, S., \& Fraser, P. (2005). Shifting paradigms of product development in fast and dynamic markets. Reliability Engineering \& System Safety, 88(2), 127-135. https://doi.org/10.1016/j.ress.2004.07.002

Monczka, R.M., Handfield, R.B., Giunipero, L.C., \& Patterson, J.L. (2015). Purchasing and supply-chain management. 6th ed. Boston MA: Cengage Learning.

Nijssen, E.J., Biemans, W.G., \& De Kort, J.F. (2002). Involving purchasing in new product development. R\&D Management, 32(4), 281-289. https://doi.org/10.1111/1467-9310.00260

Otto, K., \& Wood, K. (2001). Product design: techniques in reverse engineering and new product design. Upper Saddle River, NJ: Prentice-Hall.

Pahl, G., \& Beitz, W. (2013). Engineering design: a systematic approach. Berlin: Springer Science \& Business Media.

Pero, M., Abdelkafi, N., Sianesi, A., \& Blecker, T. (2010). A framework for the alignment of new product development and supply chains. Supply Chain Management: An International Journal, 15(2), 115-128. https://doi.org/10.1108/13598541011028723 
Petersen, K.J., Handfield, R.B., \& Ragatz, G.L. (2005). Supplier integration into new product development: coordinating product, process and supply chain design. Journal of operations management, 23(3), 371-388. https://doi.org/10.1016/j.jom.2004.07.009

Pooler, V.H., Pooler, D.J., \& Farney, S.D. (2007). Global purchasing and supply management: Fulfill the vision. 2nd ed. New York, NY: Springer Science \& Business Media.

Pufall, A., Fransoo, J.C., \& de Kok, A.G. (2007). What determines product ramp-up performance?: A review of characteristics based on a case study at Nokia Mobile Phones. BETA Publicatie: Working Paper, No. 228. Technische Universiteit Eindhoven, Netherlands.

Pufall, A., Fransoo, J.C., de Jong, A., \& de Kok, T. (2012). The impact of product complexity on ramp-up performance. Working paper, Beta publicatie, Eindhoven University of Technology, Netherlands.

Ragatz, G.L., Handfield, R.B., \& Scannell, T.V. (1997). Success factors for integrating suppliers into new product development. Journal of product innovation management, 14(3), 190-202. https://doi.org/10.1016/S07376782(97)00007-6

Salvador, F., Forza, C., \& Rungtusanatham, M. (2002). Modularity, product variety, production volume, and component sourcing: theorizing beyond generic prescriptions. Journal of Operations Management, 20(5), 549-575. https://doi.org/10.1016/S0272-6963(02)00027-X

Scharl, A., Gebauer, J., \& Bauer, C. (2001). Matching process requirements with information technology to assess the efficiency of web information systems. Information Technology and Management, 2(2), 193-210. https://doi.org/10.1023/A:1011465618993

Schmidt, J.B., Sarangee, K.R., \& Montoya, M.M. (2009). Exploring new product development project review practices. Journal of Product Innovation Management, 26(5), 520-535. https://doi.org/10.1111/j.15405885.2009.00678.x

Selldin, E., \& Olhager, J. (2007). Linking products with supply chains: testing Fisher's model. Supply Chain Management: An International Journal, 12(1), 42-51. https://doi.org/10.1108/13598540710724392

Shamsuzzoha, A.H.M., Takala, J., \& Helo, P.T. (2010). Strategic outsourcing: status and prospects in global product development processes. International Journal of Management and Enterprise Development, 9(1), 30-42. https://doi.org/10.1504/IJMED.2010.035306

Shepherd, C., \& Ahmed, P.K. (2000). NPD frameworks: a holistic examination. European Journal of Innovation Management, 3(3), 160-173. https://doi.org/10.1108/14601060010341166

Skjøtt-Larsen, T., Kotzab, H., \& Grieger, M. (2003). Electronic marketplaces and supply chain relationships. Industrial Marketing Management, 32(3), 199-210. https://doi.org/10.1016/S0019-8501(02)00263-8 
Spina, G., Caniato, F., Luzzini, D., \& Ronchi, S. (2013). Past, present and future trends of purchasing and supply management: An extensive literature review. Industrial Marketing Management, 42(8), 1202-1212. https://doi.org/10.1016/j.indmarman.2013.04.001

Stauder, J., Buchholz, S., Klocke, F., \& Mattfeld, P. (2014). A new framework to evaluate the process capability of production technologies during production ramp-up. Procedia CIRP, 20, 126-131. https://doi.org/10.1016/j.procir.2014.05.043

Su, J., \& Gargeya, V.B. (2012). Strategic sourcing, sourcing capability and firm performance in the US textile and apparel industry. Strategic Outsourcing: An International Journal, 5(2), 145-165. https://doi.org/10.1108/17538291211257592

Surbier, L., Alpan, G., \& Blanco, E. (2014). A comparative study on production ramp-up: state-of-the-art and new challenges. Production Planning \& Control, 25(15), 1264-1286.

https://doi.org/10.1080/09537287.2013.817624

Swafford, P.M., Ghosh, S., \& Murthy, N. (2006). The antecedents of supply chain agility of a firm: scale development and model testing. Journal of Operations Management, 24(2), 170-188.

https://doi.org/10.1016/j.jom.2005.05.002

Tan, K.C. (2001). A framework of supply chain management literature. European Journal of Purchasing \& Supply Management, 7(1), 39-48. https://doi.org/10.1016/S0969-7012(00)00020-4

Terwiesch, C., Bohn, R., \& Chea, K. (2001). International product transfer and production ramp-up: a case study from the data storage industry. R\&D Management, 31(4), 435-451. https://doi.org/10.1111/14679310.00230

Tracey, M., Lim, J.S., \& Vonderembse, M.A. (2005). The impact of supply-chain management capabilities on business performance. Supply Chain Management: An International Journal, 10(3), 179-191. https://doi.org/10.1108/13598540510606232

Trent, R.J. (2007). Strategic supply management: creating the next source of competitive ad-vantage. Fort Lauderdale, FL: J. Ross Publishing.

Ulrich, K.T., \& Eppinger, S.D. (2008). Product Design and Development. 4th ed. New York, NY: McGraw-Hill.

Um, J., Lyons, A., Lam, H.K., Cheng, T.C.E., \& Dominguez-Pery, C. (2017). Product variety management and supply chain performance: A capability perspective on their relationships and competitiveness implications. International Journal of Production Economics, 187, 15-26. https://doi.org/10.1016/j.ijpe.2017.02.005 
Van Echtelt, F.E., Wynstra, F., Van Weele, A.J., \& Duysters, G. (2008). Managing supplier involvement in new product development: a multiple-case study. Journal of Product Innovation Management, 25(2), 180-201. https://doi.org/10.1111/j.1540-5885.2008.00293.x

Van Hoek, R., \& Chapman, P. (2006). From tinkering around the edge to enhancing revenue growth: supply chain-new product development. Supply Chain Management: An International Journal, 11(5), 385-389. https://doi.org/10.1108/13598540610682390

Van Hoek, R., \& Chapman, P. (2007). How to move supply chain beyond cleaning up after new product development. Supply Chain Management: An International Journal, 12(4), 239-244.

https://doi.org/10.1108/13598540710759745

Von Cube, J.P., \& Schmitt, R. (2014). Execution of Ramp-up Projects in Day-to-Day Operations through a Quantitative Risk Management Approach. Procedia CIRP, 20, 26-31.

https://doi.org/10.1016/j.procir.2014.06.143

Wynstra, F., \& Ten Pierick, E. (2000). Managing supplier involvement in new product development: a portfolio approach. European Journal of Purchasing \& Supply Management, 6(1), 49-57. https://doi.org/10.1016/S0969-7012(99)00035-0

Wynstra, F., Weele, A.V., \& Axelsson, B. (1999). Purchasing involvement in product development: a framework. European Journal of Purchasing \& Supply Management, 5(3-4), 129-141. https://doi.org/10.1016/S0969-7012(99)00017-9

Yin, R.K. (2003). Case study research: Design and methods. 3rd ed. Beverly Hills, CA: Sage Publications Inc.

Zsidisin, G.A., \& Ellram, L.M. (2001). Activities related to purchasing and supply management involvement in supplier alliances. International journal of physical distribution \& logistics management, 31(9), 629-646. https://doi.org/10.1108/09600030110408143

Journal of Industrial Engineering and Management, 2017 (www.jiem.org)

Article's contents are provided on an Attribution-Non Commercial 3.0 Creative commons license. Readers are allowed to copy, distribute and communicate article's contents, provided the author's and Journal of Industrial Engineering and Management's names are included. It must not be used for commercial purposes. To see the complete license contents, please visit http://creativecommons.org/licenses/by-nc/3.0/. 